\title{
ASSESSING SUSTAINABILITY INITIATIVES IN HIGHER EDUCATION INSTITUTIONS
}

\author{
JUSTIN EDRIC G. YTURZAETA \\ Ateneo de Manila University \\ justinyturzaeta@yahoo.com
}

\begin{abstract}
This study investigates how sustainability initiatives in higher education institutions (HEIs) can be assessed. As educational institutions, HEIs are more focused on the academic aspects of sustainability although many have also made strides to address environmental, social, and governance concerns. One assessment tool, developed based on Hart and Milstein's (2003) Sustainable Value Framework, looks at the sustainability value of a HEI according to two dimensions: a temporal dimension that determines whether or not a HEI's sustainability initiatives address either present concerns or long-term goals and an organizational boundary dimension that classifies the initiatives as responses to either the internal or external concerns of the organization. The tool gives a rapid sustainability assessment of HEIs and can help them manage their sustainability efforts to maximize the sustainable value created in their own special contexts. HEIs that are committed to mainstreaming sustainability can thus use the adapted conceptual framework as a means for both assessment and planning. For the purposes of this study, semi-structured interviews with nine private HEIs in Metro Manila were conducted to gather information about their current sustainability initiatives while sustainability context and content analysis was performed to determine their position within the assessment tool's framework.
\end{abstract}

\section{KEYWORDS}

rapid sustainability assessment tool; sustainable value creation; sustainability initiatives; higher education institutions 


\title{
INTRODUCTION
}

Higher education institutions (or HEIs, which include universities, colleges, polytechnics, etc.) face a challenge in that they must ensure not only that sustainable development is central to their education, research, management, and communication but also that the educational environment is itself sustainable as well (van Weenen, 2000). A sustainable university must be able to manage economic growth, environmental conservation, cultural awareness, and social responsibility simultaneously (Lukman \& Glavič, 2007). It is

\begin{abstract}
a higher educational institution, as a whole or as a part, that addresses, involves and promotes, on a regional or a global level, the minimization of negative environmental, economic, societal, and health effects generated in the use of their resources in order to fulfill its functions of teaching, research, outreach and partnership, and stewardship in ways [that] help society make the transition to sustainable lifestyles. (Velazquez, Munguia, Platt, \& Taddei, 2006: 812)
\end{abstract}

\section{SUSTAINABILITY IN HIGHER EDUCATION}

There are conceptual frameworks for sustainability in higher education that have been suggested. Velazquez et al. (2006) proposed a sustainable university model that begins with the conceptualization of a sustainability vision and the organization of a sustainability committee at the decision-making level to help facilitate and coordinate sustainability initiatives across four categories: education, research, outreach and partnership, and sustainability on campus. Lukman and Glavič (2007) promoted the "Plan-Do-Check-Act" cycle as a management philosophy for the implementation of sustainability activities in universities along with the integration of sustainability into everyday activities, including "management performance, education and research, operations, forming networks, and reporting to stakeholders."

Alshuwaikhat and Abubakar (2008) presented a framework for achieving campus sustainability by focusing on three key areas, namely, a university's 1) environmental management system (EMS), 2) public participation and social responsibility, and 3) sustainability teaching and research. De Castro and Jabbour (2013) then evaluated the sustainability of an Indian university by assessing whether it was implementing activities formally or informally according to the elements of Alshuwaikhat and Abubakar's (2008) framework or if there was no evidence of such activities. 
Shi and Lai (2013) proposed a university sustainability rating framework based on the assessment criteria of the Sustainability Tracking, Assessment \& Rating System ${ }^{\mathrm{TM}}$ (STARS), American Colleges and Universities Presidents' Climate Commitment (ACUPCC), and Green Report Card. In their comparative analysis of four sustainability assessment tools for higher education institutions, Berzosa, Bernaldo, and Fernández-Sanchez (2017) focused on four general areas of sustainability, namely, social, curricular, environmental, and economic. Some campus sustainability assessment frameworks have also been suggested based on the experience of particular universities (Beringer, 2006; Mitchell, 2011; Saadatian, Salleh, Tahir, Haw, \& Sopian, 2011; Fadzil, Hashim, Che-Ani, \& Aziz, 2012; Ercilla, 2017).

There are also published articles about the sustainability of particular HEIs such as those in China (Geng, Liu, Xue, \& Fujita, 2013; Xiong, Fu, Duan, Liu, Yang, \& Wang, 2013; Yuan, Zuo, \& Huisingh, 2013; Tan, Chen, Shi, \& Wang, 2014), Canada (Beringer, 2006; Beringer, Wright, \& Malone, 2008; Fonseca, Macdonald, Dandy, \& Valenti, 2011; Mitchell, 2011; Vaughter, McKenzie, Lidstone, \& Wright, 2016), Malaysia (Saadatian et al., 2011; Fadzil et al., 2012; Foo, 2013), and the Philippines (Galang, 2010; Segovia \& Galang, 2002; Ogoc, 2015; Ibarrientos, 2015; Ercilla, 2017). There were also studies that covered groups of HEIs, e.g., 40 Spanish universities (Larrán Jorge, Herrera Madueño, Calzado Cejas, \& Andrades Peña, 2015) and 53 Portuguese HEIs (Aleixo, Azeiteiro, \& Leal, 2018).

\section{THE SUSTAINABLE VALUE CREATION FRAMEWORK}

Hart and Milstein (2003: 65) defined sustainable value as "shareholder wealth that simultaneously drives us toward a more sustainable world." They proposed a sustainable value framework with two dimensions: temporal (today-tomorrow) and organizational boundary (internal-external). The temporal dimension, represented by the vertical axis, depicts the creative tension between creating value today while preparing for the changes of tomorrow's markets. The organizational boundary dimension, represented by the horizontal axis, depicts the creative tension between developing the organization's internal capabilities while gaining insights from interactions with external stakeholders. These two dimensions form the framework's four quadrants, each with its own sustainability drivers, strategies, and corporate payoff (Figure 1). 


\section{Key dimensions of performance to generate shareholder value}

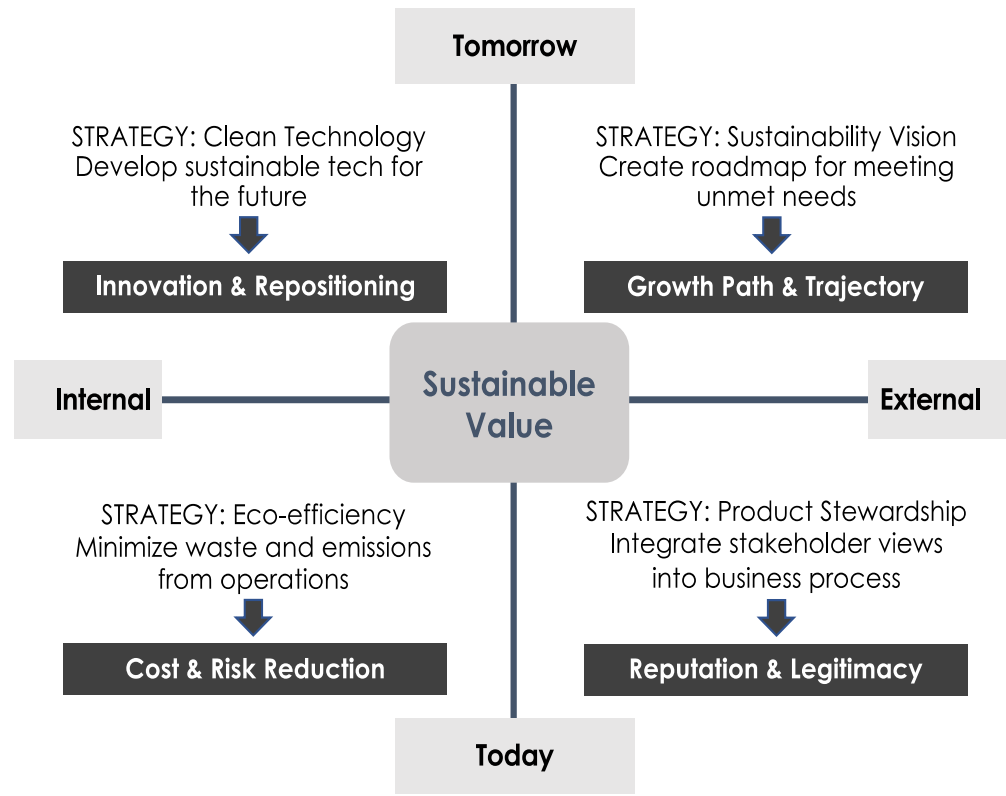

Figure 1: Sustainable Value Framework (adapted from Hart \& Milstein, 2003)

For Hart and Milstein (2003), the drivers for sustainability in the internal-today quadrant rose from industrial activity that has led to an increase in consumption and the production of pollution and waste. Companies can thus reduce their costs and risks by producing less waste, which leads to lower waste disposal costs, and by becoming more efficient in their use of raw materials. Such pollution prevention strategies, however, require not only the implementation of continuous improvement, quality management, and environmental management systems but also the extensive involvement of employees. Dao, Langella, \& Carbo (2011) argue that creating sustainable value in the internal-today quadrant requires human resources that are managed well to ensure that current operations are sustainable while simultaneously recognizing the upholding of employee well-being as part of the moral responsibilities of the company.

Hart and Milstein (2003) also suggest that advances in information and communications technologies have led to greater interconnectivity among civil society stakeholders, with some of them already having begun to enforce social and 
environmental standards on companies and demand for greater transparency from firms. The corporate strategy in the external-today quadrant, therefore, is product stewardship, which involves not only being responsible for the company's products throughout their lifecycle but also integrating the views of stakeholders into the business. Such involvement with external stakeholders eventually results in an improved corporate reputation and legitimacy. Dao et al. (2011), moreover, say that companies also have the opportunity to solve social issues that affect their internal and external stakeholders.

The internal-tomorrow quadrant considers emerging technologies that can be disruptive enough to make some industries obsolete while meeting the needs of billions of people, especially the poor, and maintaining a low environmental footprint (Hart \& Milstein, 2003). Acquiring such clean technologies allows companies to address social and environmental problems directly, helping them create value in the internal-tomorrow quadrant instead of simply reducing the impact of their current operations. Indeed, while investments in researching and developing such emerging technologies do not always pay off in the short-run, they can be the basis for a firm's innovation and repositioning in the market. Dao et al. (2011) extend this area by proposing that the firm must have a culture of risktaking and be able to acquire and train personnel to develop such technologies, and that companies have a responsibility of meeting their employees' long-term needs through assurances of long-term employment.

Problems arising from population growth, poverty, and inequity are an opportunity for companies to define their trajectory of growth. To create sustainable value in the external-tomorrow quadrant, firms must engage with and provide the unmet needs of previously overlooked market segments (such as the bottom-of-thepyramid market); they must envision a "more inclusive form of capitalism" (Hart \& Milstein, 2003: 63). Dao et al. (2011) argue that companies must concern themselves with human capital beyond their organization and be able to communicate their vision of sustainability throughout their supply chain.

Lastly, Hart and Milstein (2003: 58) maintain that "firms must perform well simultaneously in all four quadrants of the model on a continuous basis" and that focusing only on certain quadrants may lead to company failure. They recommend that companies or strategic business units use the Sustainable Value Framework 
as a diagnostic tool for assessing the portfolio balance of their activities across the four quadrants, arguing that "extreme portfolio imbalance suggests missed opportunities-and vulnerability." Firms can also use the framework, conversely, to identify opportunities for creating sustainable value.

This framework, though originally developed for business enterprises, can also be used to assess the sustainability initiatives of HEIs. Schools create value which they offer to their target market, and for-profit educational institutions can be found in different parts of the world. A school's sustainability initiatives can also be categorized according to organizational boundaries (internal vs. external) and the time frame of their implementation (today vs. tomorrow).

\section{OBJECTIVES AND DESIGN OF THIS STUDY}

Despite the existence of a number of conceptual frameworks for implementing and assessing sustainability initiatives in higher education, many HEIs have yet to invest in long-term sustainability strategies. They may be encouraged to do so, however, with a framework that makes it easy for them to understand their place in the sustainability landscape without necessarily comparing themselves with other HEIs that have other contexts and resources. This study has therefore developed an assessment tool that gives a rapid sustainability assessment of HEIs and also helps them manage their sustainability efforts to maximize the sustainable value created in their own special contexts. The tool is based on the idea that sustainability can be manifested through "the performance of environmental, social, and governance practices that increase the worth of goods and services and simultaneously drive us toward a more sustainable world" (Hart \& Milstein, 2003), a concept that can be adapted to the context of HEIs as "the performance of environmental, social, governance, and academic practices that increase the worth of educational services and simultaneously drive us toward a more sustainable world." This revised definition goes beyond the creation of wealth (i.e., profit) and considers a HEI's educational mission, reputation, and development path, all of which contribute to and yield long-term growth for the HEI. The created value, therefore, must have positive impacts on the environment and/or society to be considered sustainable.

This research work followed a multiple-case study design (Yin, 2003) that involved nine private HEIs (three not-for-profits and six for-profits) operating 
in Metro Manila, Philippines. HEIs were selected based on their relative size and influence in the region, the presence of sustainability initiatives on their campuses, and the structure of their private ownership. The resulting sample, however, included only those HEIs that responded.

Semi-structured interviews (Longhurst, 2010) with key sustainability informants or point persons from each HEI, that is, with the head of the HEI's sustainability office or its closest equivalent, were conducted. The interviews consisted of two main sections that focused on sustainability context and initiatives. The first section included questions on the following: the HEI's definition of sustainability, the history of sustainability at the HEI, the presence of strategic plans or policies regarding sustainability, and the drivers or motivations that led to the sustainability initiatives at the HEI. For the second section, the interviewees were asked to enumerate the sustainability initiatives of their respective HEIs and describe briefly what occurs in each initiative. To organize the enumeration of the sustainability initiatives, two questions per quadrant for each of the dimensions of sustainability (environmental, social, governance, academic) were formulated based on the strategies presented in the conceptual framework, thereby yielding a total of 32 guide questions. Openended questions were also asked to cover other sustainability initiatives.

Content analysis (Elo \& Kyngäs, 2008) was performed on the transcripts to understand the sustainability contexts of the HEIs and determine both the sustainable value created from their sustainability initiatives and the general trend behind them.

\section{DISCUSSION OF RESULTS}

Motivations to pursue sustainability. Among the motivations to pursue sustainability were the desires to preserve the natural environment and ensure the operational viability of the institution. The HEIs recognized the need to reduce the environmental impact of their operations, especially their carbon emissions, with one HEI implementing a carbon footprint reduction campaign and another forming an in-house climate change committee. The general direction of environmental management was to conserve whatever resources were consumed and minimize waste and pollution generated. 
Quality and excellence in education along with improvements in the bottom line were pursued to ensure the operational viability of the institution. In line with what was mentioned in the previous section, a reputation for quality usually led to increased enrollment, which consequently improved a HEI's bottom line. Many HEIs also mentioned that their initiatives in pursuing environmental sustainability led to cost savings for their institutions, with such a concern for costs and profits being more pronounced in for-profit institutions that had obligations to their stockholders.

Drivers for sustainability. The results of the content analysis of the sustainability context were examined with respect to the sustainable value framework to determine the guiding principles that drove sustainability in each quadrant. The drivers for the internal-today quadrant were the concern for people, planet, and profit in the institution over the short term and pursuit of quality in the HEI's education and operations. For the internal-tomorrow quadrant, the drivers were sustainability leadership and the desire for institutional sustainability. The drivers for the external-today quadrant were concerns for the institution's general reputation and for people and the environment beyond its physical boundaries. Lastly, for the external-tomorrow quadrant, the drivers were sustainability challenges in society and the desire to contribute to sustainable development goals. Figure 2 summarizes the drivers for sustainability per quadrant.

Sustainability Initiatives. Content analysis (Elo \& Kyngäs, 2008) was performed on the transcripts of the second sections of the interviews to determine sustainable value creation from the sustainability initiatives of the HEIs as well as the general trend behind them. The sustainability initiatives of the HEIs were first classified according to the dimension where the impact was intended to occur, namely environmental, social, and governance. A fourth dimension-the academic dimension-was created for initiatives that deal with sustainability curricula and research. The number of initiatives, which were distributed among the four dimensions, came from the interviews and from documents referred by the interviewees (Table 1).

The initiatives in each dimension (environmental, social, governance, and academic) were then classified into types according to common themes or directions, e.g., initiatives for using energy-efficient appliances and for having energy conservation policies in place were grouped under "energy conservation \& 
efficiency." They were then classified according to their organizational boundaries (i.e., are initiatives implemented internally for the HEI or externally with other stakeholders?) and timeframes (i.e., are initiatives tactical and for the short term or are they strategic and for the long term?). The results were summarized according to the environmental (Table 2), social (Table 3), governance (Table 4), and academic (Table 5) dimensions. These tables consequently became the basis for the initiatives included in the survey questionnaire for the HEIs and for their positions in the quadrants (Table 6).

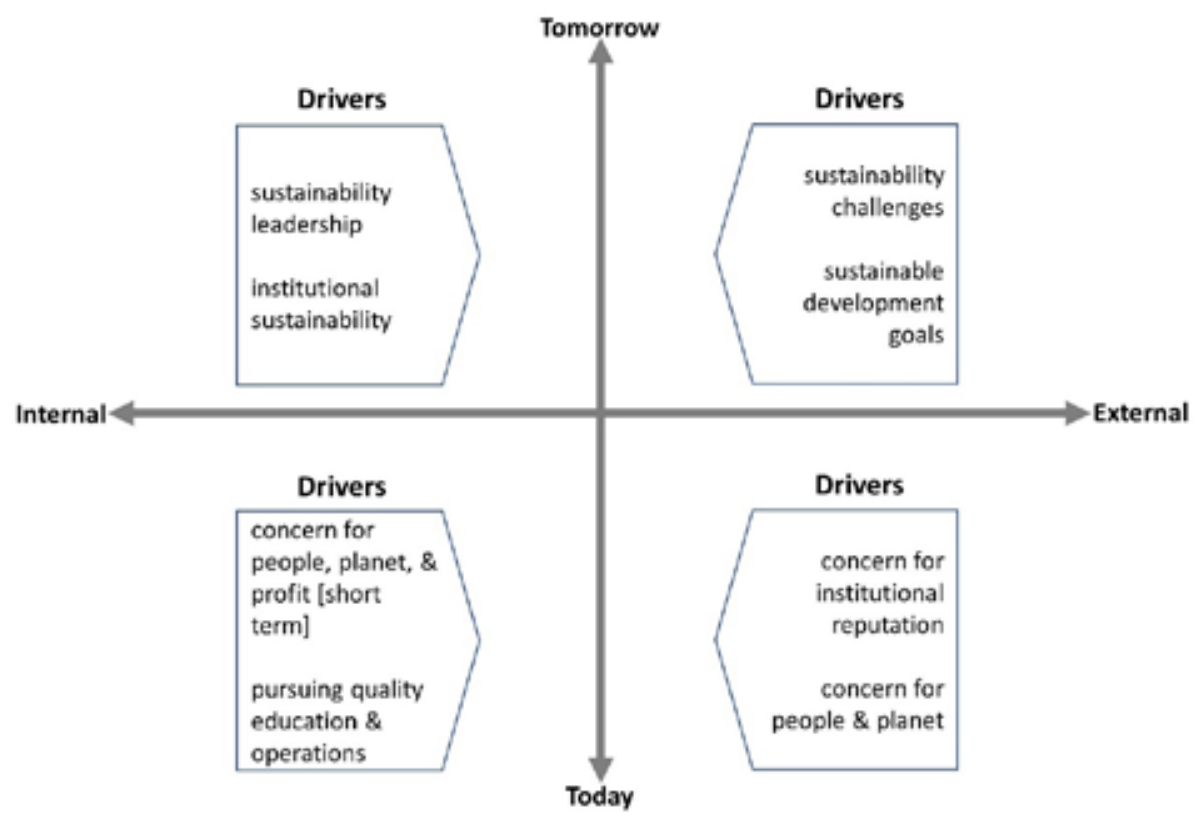

Figure 2: Drivers for Sustainability According to the Sustainable Value Framework

\begin{tabular}{|c|c|}
\hline DIMENSION & NUMBER OF HEI INITIATIVES \\
\hline Environmental & 50 \\
\hline Social & 50 \\
\hline Governance & 50 \\
\hline Academic & 45 \\
\hline Total & 195 \\
\hline
\end{tabular}

Table 1: Overview of HEl Initiatives per Dimension for All Nine HEls 


\begin{tabular}{|c|c|c|c|}
\hline TYPE OF INITIATIVE & $\begin{array}{c}\text { NUMBER } \\
\text { OF HEIs }^{\mathrm{a}}\end{array}$ & $\begin{array}{c}\text { INTERNAL/ } \\
\text { EXTERNAL }^{\mathrm{b}}\end{array}$ & $\begin{array}{c}\text { TODAY/ } \\
\text { TOMORROW }^{\mathrm{b}}\end{array}$ \\
\hline $\begin{array}{c}\text { waste management } \\
\text { restoration/rehabilitation of the } \\
\text { natural environment }\end{array}$ & 9 & Internal & Today \\
\hline energy conservation \& efficiency & 8 & External & Tomorrow \\
\hline supplies conservation & 8 & Internal & Today \\
\hline environmental management & 8 & Internal & Today \\
\hline environmental cleanup & 7 & External & Today \\
\hline partnerships for the environment & 7 & External & Tomorrow \\
\hline promoting eco-friendly behaviors & 6 & Internal & Today \\
\hline water conservation & 6 & Internal & Today \\
\hline promoting eco-friendly \\
behaviors [external]
\end{tabular}

Table 2: Types of Initiatives under the Environmental Dimension

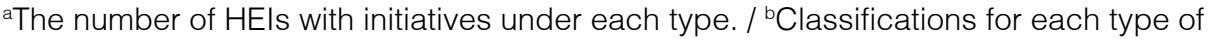
initiative are based on the Hart \& Milstein (2003) framework.

\begin{tabular}{|c|c|c|c|}
\hline TYPE OF INITIATIVE & $\begin{array}{l}\text { NUMBER } \\
\text { OF HEIs }\end{array}$ & $\begin{array}{l}\text { INTERNAL/ } \\
\text { EXTERNAL }\end{array}$ & $\begin{array}{c}\text { TODAY/ } \\
\text { TOMORROW }\end{array}$ \\
\hline employee training & 9 & Internal & Today \\
\hline employee benefits and incentives & 9 & Internal & Today \\
\hline safety \& security & 9 & Internal & Today \\
\hline physical health \& well-being & 9 & Internal & Today \\
\hline faculty and staff development & 9 & Internal & Tomorrow \\
\hline partnerships for social good & 9 & External & Tomorrow \\
\hline extension work/civic work & 9 & External & Today \\
\hline mental \& emotional health & 8 & Internal & Today \\
\hline involvement in policy making & 7 & External & Tomorrow \\
\hline centers for social good & 7 & External & Tomorrow \\
\hline
\end{tabular}




\begin{tabular}{|c|c|c|c|}
\hline TYPE OF INITIATIVE & $\begin{array}{l}\text { NUMBER } \\
\text { OF HEls }{ }^{a}\end{array}$ & $\begin{array}{l}\text { INTERNAL/ } \\
\text { EXTERNAL }^{\mathrm{b}}\end{array}$ & $\begin{array}{c}\text { TODAY/ } \\
\text { TOMORROW }\end{array}$ \\
\hline career placement & 3 & External & Today \\
\hline values formation & 2 & Internal & Tomorrow \\
\hline university statements for justice & 1 & External & Today \\
\hline preserving cultural heritage & 1 & External & Tomorrow \\
\hline social inclusion program & 1 & Internal & Today \\
\hline
\end{tabular}

Table 3: Types of Initiatives under the Social Dimension

aThe number of HEls with initiatives under each type. / ${ }^{b}$ Classifications for each type of initiative are based on the Hart \& Milstein (2003) framework.

\begin{tabular}{|c|c|c|c|}
\hline TYPE OF INITIATIVE & $\begin{array}{c}\text { NUMBER } \\
\text { OF HEIs }\end{array}$ & $\begin{array}{c}\text { INTERNAL/ } \\
\text { EXTERNAL }^{b}\end{array}$ & $\begin{array}{c}\text { TODAY/ } \\
\text { TOMORROW }^{\mathrm{b}}\end{array}$ \\
\hline feedback mechanisms [internal] & 9 & Internal & Today \\
\hline accreditations, awards, and recognitions & 9 & External & Today \\
\hline $\begin{array}{c}\text { management policies and } \\
\text { operating guidelines }\end{array}$ & 8 & Internal & Today \\
\hline management systems & 8 & Internal & Today \\
\hline feedback mechanisms & 7 & External & Today \\
\hline sharing best practices & 7 & External & Today \\
\hline $\begin{array}{c}\text { quality management and } \\
\text { continuous improvement }\end{array}$ & 7 & Internal & Tomorrow \\
\hline promoting organizational values & 6 & Internal & Today \\
\hline disclosure and transparency & 5 & External & Today \\
\hline membership in inter-HEI organizations & 5 & External & Tomorrow \\
\hline internal management reporting & 4 & Internal & Today \\
\hline environment as & 3 & Internal & Tomorrow \\
\hline top management priority & 2 & Internal & Today \\
\hline sustainability policies/guidelines & 2 & External & Tomorrow \\
\hline partnerships for good governance & 2 & Internal & Tomorrow \\
\hline succession planning & Internal & Tomorrow \\
\hline sustainability systems & 1 & & \\
\hline
\end{tabular}

Table 4: Types of Initiatives under the Governance Dimension aThe number of HEls with initiatives under each type. / ${ }^{\mathrm{b}} \mathrm{Classifications}$ for each type of initiative are based on the Hart \& Milstein (2003) framework. 


\begin{tabular}{|c|c|c|c|}
\hline TYPE OF INITIATIVE & $\begin{array}{c}\text { NUMBER } \\
\text { OF HEIs }^{\mathrm{a}}\end{array}$ & $\begin{array}{c}\text { INTERNAL/ } \\
\text { EXTERNAL }^{\mathrm{b}}\end{array}$ & $\begin{array}{c}\text { TODAY/ } \\
\text { TOMORROW }^{\mathrm{b}}\end{array}$ \\
\hline partnerships for research and curriculum & 9 & External & Tomorrow \\
\hline communicating sustainability knowledge & 8 & External & Today \\
\hline integration of sustainability into research & 7 & Internal & Today \\
\hline integration of sustainability into courses & 6 & Internal & Today \\
\hline sustainability courses and programs & 6 & Internal & Tomorrow \\
\hline developing sustainability solutions & 4 & External & Tomorrow \\
\hline sustainability research programs & 4 & Internal & Tomorrow \\
\hline service learning & 3 & External & Today \\
\hline attending sustainability-related events & 3 & External & Today \\
\hline developing skills for sustainability & 2 & External & Tomorrow \\
\hline developing change-agents for sustainability & 2 & External & Tomorrow \\
\hline research positions & 2 & Internal & Today \\
\hline promoting research ethics & 1 & Internal & Today \\
\hline
\end{tabular}

Table 5: Types of Initiatives under the Academic Dimension

aThe number of HEls with initiatives under each type. / ${ }^{\mathrm{b}} \mathrm{Classifications} \mathrm{for} \mathrm{each} \mathrm{type} \mathrm{of}$ initiative are based on the Hart \& Milstein (2003) framework.

Please indicate with a checkmark those initiatives that are currently being implemented by your school and which can be classified under the following items

\begin{tabular}{|c|c|c|c|}
\hline \multicolumn{5}{|c|}{ ENVIRONMENTAL DIMENSION } \\
\hline$\square$ & energy conservation \& efficiency & Internal & Today \\
\hline$\square$ & environmental management & Internal & Today \\
\hline$\square$ & pollution reduction & Internal & Today \\
\hline$\square$ & promoting eco-friendly behaviors & Internal & Today \\
\hline$\square$ & supplies conservation & Internal & Today \\
\hline$\square$ & waste management & Internal & Today \\
\hline$\square$ & water conservation & Internal & Today \\
\hline$\square$ & green buildings & Internal & Tomorrow \\
\hline$\square$ & promoting changes in lifestyle [internal] & Internal & Tomorrow \\
\hline$\square$ & renewable energy & Internal & Tomorrow \\
\hline$\square$ & environmental cleanup & External & Today \\
\hline$\square$ & promoting eco-friendly behaviors [external] & External & Today \\
\hline$\square$ & restoration/rehabilitation of the natural & External & Tomorrow \\
\hline$\square$ & environment & External & Today \\
\hline
\end{tabular}




\begin{tabular}{|c|c|c|c|}
\hline \multicolumn{4}{|c|}{ ENVIRONMENTAL DIMENSION } \\
\hline$\square$ & partnerships for the environment & External & Tomorrow \\
\hline$\square$ & other initiatives & $\begin{array}{c}\text { Internal/ } \\
\text { External? }\end{array}$ & $\begin{array}{c}\text { Today/ } \\
\text { Tomorrow? }\end{array}$ \\
\hline
\end{tabular}

\begin{tabular}{|c|c|c|c|}
\hline \multicolumn{5}{|c|}{ SOCIAL DIMENSION } \\
\hline$\square$ & employee training & Internal & Today \\
\hline$\square$ & employee benefits and incentives & Internal & Today \\
\hline$\square$ & mental \& emotional health & Internal & Today \\
\hline$\square$ & physical health \& well-being & Internal & Today \\
\hline$\square$ & safety \& security & Internal & Today \\
\hline$\square$ & social inclusion program & Internal & Today \\
\hline$\square$ & faculty and staff development & Internal & Tomorrow \\
\hline$\square$ & values formation & Internal & Tomorrow \\
\hline$\square$ & career placement & External & Today \\
\hline$\square$ & extension work/civic work & External & Today \\
\hline$\square$ & university statements for justice & External & Today \\
\hline$\square$ & centers for social good & External & Tomorrow \\
\hline$\square$ & involvement in policy making & External & Tomorrow \\
\hline$\square$ & partnerships for social good & External & Tomorrow \\
\hline$\square$ & preserving cultural heritage & External & Tomorrow \\
\hline$\square$ & other initiatives & Internal/ & Today/ \\
\hline
\end{tabular}

\begin{tabular}{|c|c|c|c|}
\hline \multicolumn{4}{|c|}{ GOVERNANCE DIMENSION } \\
\hline$\square$ & feedback mechanisms [internal] & Internal & Today \\
\hline$\square$ & internal management reporting & Internal & Today \\
\hline$\square$ & management policies and operating guidelines & Internal & Today \\
\hline$\square$ & management systems & Internal & Today \\
\hline$\square$ & promoting organizational values & Internal & Today \\
\hline$\square$ & sustainability policies/guidelines & Internal & Today \\
\hline$\square$ & environment as top management priority & Internal & Tomorrow \\
\hline$\square$ & quality management and & Internal & Tomorrow \\
\hline$\square$ & continuous improvement & Internal & Tomorrow \\
\hline$\square$ & succession planning & Internal & Tomorrow \\
\hline$\square$ & accreditations, awards, and recognitions & External & Today \\
\hline$\square$ & disclosure and transparency & External & Today \\
\hline
\end{tabular}




\begin{tabular}{|c|c|c|c|}
\hline \multicolumn{4}{|c|}{ GOVERNANCE DIMENSION } \\
\hline$\square$ & feedback mechanisms & External & Today \\
\hline$\square$ & sharing best practices & External & Today \\
\hline$\square$ & membership in inter-HEI organizations & External & Tomorrow \\
\hline$\square$ & partnerships for good governance & External & Tomorrow \\
\hline$\square$ & other initiatives & Internal/ & Today/ \\
& & External? & Tomorrow? \\
\hline
\end{tabular}

\begin{tabular}{|c|c|c|c|}
\hline \multicolumn{4}{|c|}{ ACADEMIC DIMENSION } \\
\hline$\square$ & integration of sustainability into research & Internal & Today \\
\hline$\square$ & integration of sustainability into courses & Internal & Today \\
\hline$\square$ & research positions & Internal & Today \\
\hline$\square$ & promoting research ethics & Internal & Today \\
\hline$\square$ & sustainability courses and programs & Internal & Tomorrow \\
\hline$\square$ & sustainability research programs & Internal & Tomorrow \\
\hline$\square$ & attending sustainability-related events & External & Today \\
\hline$\square$ & communicating sustainability knowledge & External & Today \\
\hline$\square$ & service learning & External & Today \\
\hline$\square$ & sharing best practices & External & Today \\
\hline$\square$ & membership in inter-HEI organizations & External & Tomorrow \\
\hline$\square$ & partnerships for good governance & External & Tomorrow \\
\hline$\square$ & developing change-agents for sustainability & External & Tomorrow \\
\hline$\square$ & developing skills for sustainability & External & Tomorrow \\
\hline$\square$ & other initiatives & Internal/ & Today/ \\
\hline
\end{tabular}

Table 6: Rapid Sustainability Assessment Tool

After the questionnaire was completed, the initiatives could then be plotted across the four quadrants of the framework adopted from Hart and Milstein (2003), with the bar graph giving a visual overview of the various initiatives of the HEI (Figure 3).

Applying the framework to sustainability initiatives. By distributing its initiatives accordingly across the quadrants, a HEI can have an overview of its sustainability efforts. Initiatives for the internal-today quadrant, for example, show a focus on the organization and its internal stakeholders and are more short-term 
in their implementation and impact. Table 7 shows the types of initiatives per dimension and the number of HEIs with initiatives in each type for the internaltoday quadrant. It reveals that the sustainable value created from the environmental initiatives was mainly cost and risk reduction for the HEI, its lower environmental footprint, and the eco-friendly behaviors of its members. Initiatives in the social dimension led to increased productivity in the institution while reducing humanrelated risks and promoting the health, safety, and well-being of its members. Initiatives in the governance dimension led to quality systems and good governance within the institution, all while promoting the well-being of its members by obtaining and responding to their feedback and concerns. Through initiatives in the academic dimension, the HEI fulfilled its mission in terms of education and increased awareness of sustainability challenges in the environment and in society and of the possible solutions to address such. The potential outcome for this quadrant, in summary, is focused on institutional, environmental, and social well-being.

Key dimensions of performance to generate shareholder value

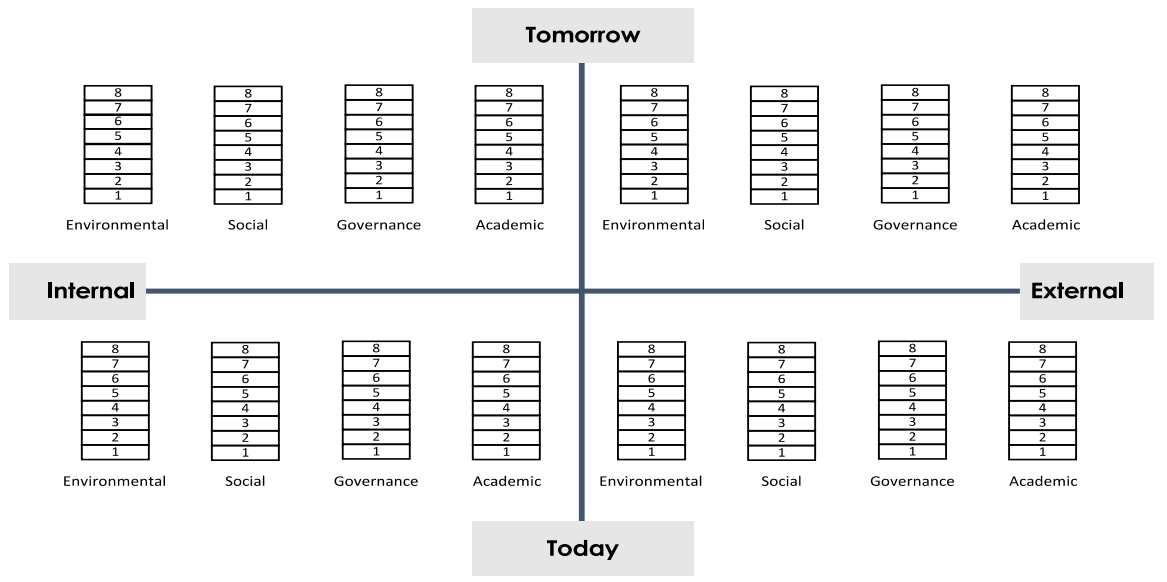

Figure 3: Template for Plotting the Initiatives on the Adapted Conceptual Framework of Hart and Milstein (2003) 


\begin{tabular}{|c|c|c|}
\hline DIMENSION & TYPE OF INITIATIVE & $\begin{array}{l}\text { NUMBER } \\
\text { OF HEIs }^{a}\end{array}$ \\
\hline Environmental & waste management & 9 \\
\hline Environmental & energy conservation \& efficiency & 8 \\
\hline Environmental & supplies conservation & 8 \\
\hline Environmental & environmental management & 8 \\
\hline Environmental & promoting eco-friendly behaviors & 6 \\
\hline Environmental & water conservation & 6 \\
\hline Environmental & pollution reduction & 2 \\
\hline Social & employee training & 9 \\
\hline Social & employee benefits and incentives & 9 \\
\hline Social & safety \& security & 9 \\
\hline Social & physical health \& well-being & 9 \\
\hline Social & mental \& emotional health & 8 \\
\hline Social & social inclusion program & 1 \\
\hline Governance & feedback mechanisms & 9 \\
\hline Governance & management policies and operating guidelines & 8 \\
\hline Governance & management systems & 8 \\
\hline Governance & promoting organizational values & 6 \\
\hline Governance & internal management reporting & 4 \\
\hline Governance & sustainability policies/guidelines & 2 \\
\hline Academic & integration of sustainability into research & 7 \\
\hline Academic & integration of sustainability into courses & 6 \\
\hline Academic & research positions & 2 \\
\hline Academic & promoting research ethics & 1 \\
\hline
\end{tabular}

Table 7: Types of Initiatives per Dimension for the Internal-Today Quadrant aThe number of HEls with initiatives under each type.

While their impact is also focused on the organization and its internal stakeholders, the initiatives in the internal-tomorrow quadrant are more longterm and strategic in their implementation and impact. Table 8 shows the types of initiatives per dimension for this quadrant. The environmental initiatives were concerned with long-term cost and environmental footprint reduction for both the institution and its members and with the institution's repositioning of itself as a "green campus." The social initiatives were related mostly to the quality of the HEI's human resources, and were seen to improve the personal and professional development of internal stakeholders. The initiatives in the governance dimension 
included those for quality management and continuous improvement, and the academic initiatives of having sustainability courses and research programs helped the HEI move toward becoming a campus for sustainable development research and education. These initiatives thus have the potential outcome of allowing the HEI to develop and achieve sustainability goals.

\begin{tabular}{|c|c|c|}
\hline DIMENSION & TYPE OF INITIATIVE & $\begin{array}{c}\text { NUMBER } \\
\text { OF HEIs }^{\text {a }}\end{array}$ \\
\hline Environmental & renewable energy & 5 \\
\hline Environmental & green buildings & 5 \\
\hline Environmental & promoting changes in lifestyle & 3 \\
\hline Social & faculty and staff development & 9 \\
\hline Social & values formation & 2 \\
\hline Governance & quality management and continuous improvement & 7 \\
\hline Governance & environment as top management priority & 3 \\
\hline Governance & succession planning & 2 \\
\hline Governance & sustainability systems & 1 \\
\hline Academic & sustainability courses and programs & 6 \\
\hline Academic & sustainability research programs & 4 \\
\hline
\end{tabular}

Table 8: Types of Initiatives per Dimension for the Internal-Tomorrow Quadrant aThe number of HEls with initiatives under each type.

The initiatives in the external-today quadrant are short-term in their implementation and impact, which is focused on external stakeholders. Table 9 shows the types of initiatives per dimension for this quadrant. The initiatives in the environmental dimension improved the HEI's reputation as an eco-friendly institution, and its accomplished extension and civic works led to social good. Governance initiatives included external stakeholder engagement which led the HEI to improve its reputation as a responsive institution. The initiatives in the academic dimension, meanwhile, demonstrated the HEI's role as an expert in sustainability. All these carry the potential outcome of improved institutional reputation and social responsibility.

\begin{tabular}{|c|c|c|}
\hline DIMENSION & TYPE OF INITIATIVE & $\begin{array}{c}\text { NUMBER } \\
\text { OF HEIs }\end{array}$ \\
\hline Environmental & environmental cleanup & 7 \\
\hline Environmental & promoting eco-friendly behaviors & 5 \\
\hline Environmental & environmental compliance reports & 4 \\
\hline
\end{tabular}




\begin{tabular}{|c|c|c|}
\hline DIMENSION & TYPE OF INITIATIVE & $\begin{array}{c}\text { NUMBER } \\
\text { OF HEIs }^{\text {a }}\end{array}$ \\
\hline Social & extension work/civic work & 9 \\
\hline Social & career placement & 3 \\
\hline Social & university statements for justice & 1 \\
\hline Governance & accreditations, awards, and recognitions & 9 \\
\hline Governance & feedback mechanisms & 7 \\
\hline Governance & sharing best practices & 7 \\
\hline Governance & disclosure and transparency & 5 \\
\hline Academic & communicating sustainability knowledge & 8 \\
\hline Academic & service learning & 3 \\
\hline Academic & attending sustainability-related events & 3 \\
\hline
\end{tabular}

Table 9: Types of Initiatives per Dimension for the External-Today Quadrant aThe number of HEls with initiatives under each type.

With their impact also focused on external stakeholders, the initiatives in the external-tomorrow quadrant are more long-term and strategic in their implementation and impact. Table 10 shows the types of initiatives per dimension for this quadrant. The initiatives in the environmental dimension dealt mostly with the restoration and rehabilitation of the natural environment and formation of partnerships for such ends. The social initiatives, in general, covered the formation of partnerships and establishment of centers for social good as well as involvement in policy making. Memberships in inter-HEI organizations and partnerships for good governance also allowed the HEI to improve its internal operations while sharing its best practices with other HEIs and institutions. The initiatives in the academic dimension, meanwhile, focused on forming partnerships to develop the HEI's research and curriculum and on developing sustainability solutions and the change-agents who will implement them. These initiatives thus have the development of sustainability solutions as their potential outcome.

The placement of initiatives can also be analyzed according to their degree of portfolio balance and strategic positioning. Adopting Hart \& Milstein (2003), the HEI "must perform well simultaneously in all four quadrants of the model on a continuous basis" to maximize the sustainable value it creates. Portfolio balance thus refers to how well each sustainability dimension is represented in each quadrant of the framework, while strategic positioning looks into the number of initiatives with long-term and strategic implementation and impact (i.e., those in the internal- 
tomorrow and external-tomorrow quadrants) relative to the number of initiatives with short-term and tactical implementation and impact (i.e., those in the internaltoday and external-today quadrants).

\begin{tabular}{|c|c|c|}
\hline DIMENSION & TYPE OF INITIATIVE & $\begin{array}{c}\text { NUMBER } \\
\text { OF HEIs }\end{array}$ \\
\hline Environmental & restoration/rehabilitation of the natural environment & 9 \\
\hline Environmental & partnerships for the environment & 7 \\
\hline Social & partnerships for social good & 9 \\
\hline Social & involvement in policy making & 7 \\
\hline Social & centers for social good & 7 \\
\hline Social & preserving cultural heritage & 1 \\
\hline Governance & membership in inter-HEI organizations & 5 \\
\hline Governance & partnerships for good governance & 2 \\
\hline Academic & partnerships for research and curriculum & 9 \\
\hline Academic & developing sustainability solutions & 4 \\
\hline Academic & developing skills for sustainability & 2 \\
\hline Academic & developing change-agents for sustainability & 2 \\
\hline
\end{tabular}

Table 10: Types of Initiatives per Dimension for the External-Tomorrow Quadrant aThe number of HEls with initiatives under each type.

Depending on its own sustainability principles, each HEI can also develop its own specific metrics for assessing the degree of portfolio balance of its initiatives. There should be more academic initiatives in the external-tomorrow quadrant, for example, if an HEI chooses to focus on creating sustainability solutions through research and developing change-agents for sustainability. In this case, the HEI might want a $1 \frac{1 / 2}{2}: 1$ or a $2: 1$ ratio of academic initiatives in the external-tomorrow quadrant with respect to academic initiatives in each of the other quadrants. If the HEI also wants to minimize its environmental footprint in the short term, a similar ratio may be desired for environmental initiatives in the internal-today quadrant vis-à-vis those in other quadrants.

According to Siew (2015), frameworks set principles and guidelines while standards have requirements and specifications. Ratings and indices, on the other hand, allow for comparisons and third-party evaluations. Since the different contexts of the HEIs - their geography, resources, mission, target market, and specializationsmake them incomparable in general, the adapted conceptual framework is mainly a sustainability framework rather than a sustainability standard, rating, 
or index. It provides a set of principles and guidelines that can help HEIs manage their sustainability efforts to maximize sustainable value creation in their own special contexts.

The case of University Epsilon. ${ }^{1}$ The adapted framework can be used as a template for a multi-chart figure to show the degree of portfolio balance of an HEI's sustainability initiatives at a glance. Figure 4 shows this for University Epsilon, one of the HEIs that participated in the study. The number of sustainability initiatives per dimension for each quadrant is shown through bar charts, with each color representing a different dimension. HEIs using this tool, moreover, can also integrate their own evaluation systems for their initiatives into the scatterplot (such as denoting the level of goal attainment by using different shades of color, for example).

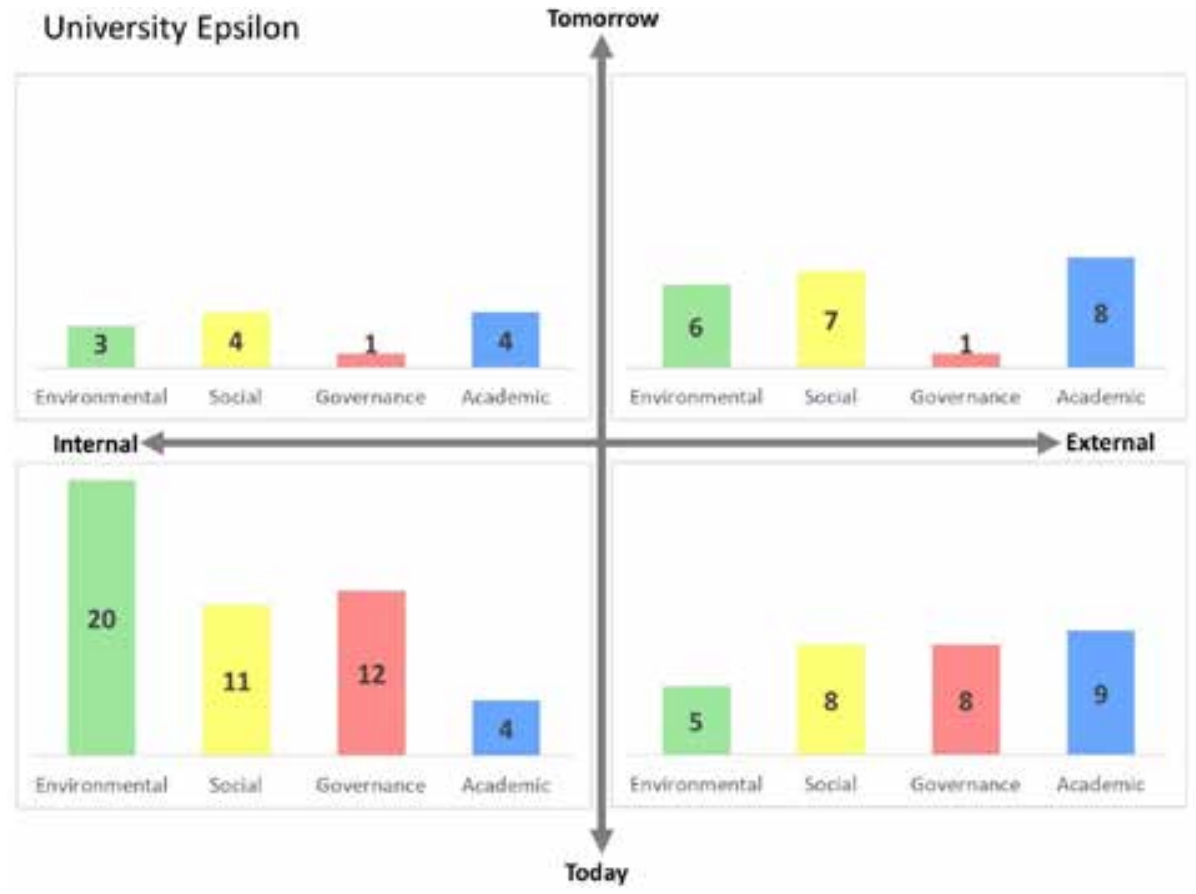

Figure 4: Sample Assessment for University Epsilon (with bar charts showing the number of initiatives per dimension for each quadrant)

The assessment of a HEI's initiatives and their sustainable value creation can thus be performed when the figure is used in conjunction with the list of initiatives. An

${ }^{1}$ Not the HEl's actual name. 
analysis of University Epsilon, for example, shows their sustainable value creation in the different quadrants. Their environmental, social, and governance initiatives are concentrated in the internal-today quadrant, with many of the environmental initiatives dealing with pollution and waste management and resource conservation. The university also has initiatives in rehabilitating and restoring the natural environment, activities which are in the external-tomorrow quadrant.

There are a lot of social initiatives in the internal-today quadrant that deal with training faculty and staff and giving them incentives while also taking care of their physical and emotional well-being. The university also has many initiatives in extension and civic works, and has established centers for social good; these are shown in the external-today and external-tomorrow quadrants. As for governance initiatives, most of them are focused on the short-term. The university has management policies, guidelines, and systems in place, and obtains feedback from internal stakeholders; these are all activities in the internal-today quadrant. Feedback mechanisms for external stakeholders, on the other hand, are also present, along with awards and recognitions from the academic and environmental initiatives of the university.

Most of the initiatives in the academic dimension, which arise from the university's efforts to develop sustainability solutions and form partnerships for research and curriculum development, are in the external-tomorrow quadrant. The university already has courses, research, and degree programs on sustainability, and communicates its knowledge well to external stakeholders through conferences and talks, trainings and workshops, publications, and consulting services.

The sustainable values created by University Epsilon, therefore, given that most of its initiatives are in the internal-today, external-today, and externaltomorrow quadrants, are the well-being of the institution itself, its members, and the environment; improved institutional reputation and social responsibility; and solutions to sustainability challenges.

\section{CONCLUSION}

This study yielded useful information for developing a rapid sustainability assessment tool for HEIs, one that can help them manage their efforts to maximize 
the sustainable value created in their own special contexts. Its novelty lies in its use of the questionnaire and framework to give a quick view of the portfolio balance of a given set of sustainability initiatives. Using the tool can also encourage HEIs to develop their own metrics and assessment methods for measuring the impact or success of each initiative within their context.

The assessment tool can be applied in future case studies of HEIs to explore the relationship between their specific contexts and the degree of portfolio balance of their sustainability efforts. A deeper analysis that considers the HEI's sustainability strategies and their motivations to pursue sustainability with respect to their efforts can also be done.

Finally, the rapid assessment tool can also be used in other sectors and industries; indeed, the types of initiatives enumerated under the environmental, social, and governance dimensions are general enough to be easily applied to other organizations while the academic dimension can be readily set aside. Future researchers can use the methodology employed in this study to determine what sustainability initiatives are relevant or material in other sectors and industries.

The author would like to acknowledge the guidance and support of his academic mentors and colleagues as well as the generosity and hospitality of the higher education institutions that participated in this study.

\section{REFERENCES}

Aleixo, A. M., Azeiteiro, U., \& Leal, S. 2018. The implementation of sustainability practices in Portuguese higher education institutions. International Journal of Sustainability in Higher Education, 19(1): 146-178.

Alshuwaikhat, H. M., \& Abubakar, I. 2008. An integrated approach to achieving campus sustainability: Assessment of the current campus environmental management practices. Journal of Cleaner Production, 16(16): 1777-1785.

Beringer, A. 2006. Campus sustainability audit research in Atlantic Canada: Pioneering the campus sustainability assessment framework. International Journal of Sustainability in Higher Education, 7(4): 437-455. 
Beringer, A., Wright, T., \& Malone, L. 2008. Sustainability in higher education in Atlantic Canada. International Journal of Sustainability in Higher Education, 9(1): 48-67.

Berzosa, A., Bernaldo, M. O., \& Fernández-Sanchez, G. 2017. Sustainability assessment tools for higher education: An empirical comparative analysis. Journal of Cleaner Production, 161: 812-820.

Dao, V., Langella, I., \& Carbo, J. 2011. From green to sustainability: Information technology and an integrated sustainability framework. Journal of Strategic Information Systems, 20(1): 63-79.

de Castro, R., \& Jabbour, C. J. C. 2013. Evaluating sustainability of an Indian university. Journal of Cleaner Production, 61: 54-58.

Elo, S., \& Kyngäs, H. 2008. The qualitative content analysis process. Journal of Advanced Nursing, 62(1): 107-115.

Ercilla, P. E. 2017. Environmental sustainability assessment of an academic institution in Calamba City. The Normal Lights, 11(1): 235-263.

Fadzil, Z., Hashim, H., Che-Ani, A., \& Aziz, S. 2012. Developing a campus sustainability assessment framework for the National University of Malaysia. International Journal of Environmental and Ecological Engineering, 6(6): 333-337.

Fonseca, A., Macdonald, A., Dandy, E., \& Valenti, P. 2011. The state of sustainability reporting at Canadian universities. International Journal of Sustainability in Higher Education, 12(1): 22-40.

Foo, K. Y. 2013. A vision on the role of environmental higher education contributing to the sustainable development in Malaysia. Journal of Cleaner Production, 61: 6-12.

Galang, A. P. 2010. Environmental education for sustainability in higher education institutions in the Philippines. International Journal of Sustainability in Higher Education, 11(2): 173-183. 
Geng, Y., Liu, K., Xue, B., \& Fujita, T. 2013. Creating a "green university" in China: A case of Shenyang University. Journal of Cleaner Production, 61: 13-19.

Hart, S., \& Milstein, M. 2003. Creating sustainable value. Academy of Management Perspectives, 17(2): 56-67.

Ibarrientos, J. A. R. 2015. Camarines Sur Polytechnic Colleges, Philippines: An eco-friendly school model. International Journal of Scientific \& Technology Research, 4(3): 203-214.

Larrán Jorge, M., Herrera Madueño, J., Calzado Cejas, M. Y., \& Andrades Peña, F. J. 2015. An approach to the implementation of sustainability practices in Spanish universities. Journal of Cleaner Production, 106: 34-44.

Longhurst, R. 2010. Semi-structured interviews and focus groups. In N. Clifford, S. French, \& G. Valentine (Eds.), Key methods in geography, 2nd ed.: 103-115. London: SAGE Publications.

Lukman, R., \& Glavič, P. 2007. What are the key elements of a sustainable university? Clean Technologies and Environmental Policy, 9(2): 103-114.

Mitchell, R. C. 2011. Sustaining change on a Canadian campus: Preparing Brock University for a sustainability audit. International Journal of Sustainability in Higher Education, 12(1): 7-21.

Ogoc, M. N. 2015. The University of Eastern Philippines: Green audit. International Journal of Information and Education Technology, 5(4): 297-302.

Saadatian, O., Salleh, E., Tahir, O. M., Haw, L. C., \& Sopian, K. 2011. A survey on campus sustainability assessment framework (CSAF) in Malaysia. Journal Design +Built, 4: 9-22.

Segovia, V. M., \& Galang, A. P. 2002. Sustainable development in higher education in the Philippines: The case of Miriam College. International Journal of Sustainability in Higher Education, 3(3): 288-297.

Shi, H., \& Lai, E. 2013. An alternative university sustainability rating framework with a structured criteria tree. Journal of Cleaner Production, 61: 59-69. 
Siew, R. Y. J. 2015. A review of corporate sustainability reporting tools (SRTs). Journal of Environmental Management, 164: 180-195.

Tan, H., Chen, S., Shi, Q., \& Wang, L. 2014. Development of green campus in China. Journal of Cleaner Production, 64: 646-653.

van Weenen, H. 2000. Towards a vision of a sustainable university. International Journal of Sustainability in Higher Education, 1(1): 20-34.

Vaughter, P., McKenzie, M., Lidstone, L., \& Wright, T. 2016. Campus sustainability governance in Canada: A content analysis of post-secondary institutions' sustainability policies. International Journal of Sustainability in Higher Education, 17(1): 16-39.

Velazquez, L., Munguia, N., Platt, A., \& Taddei, J. 2006. Sustainable university: What can be the matter? Journal of Cleaner Production, 14(9-11): 810-819.

Xiong, H., Fu, D., Duan, C., Liu, C. E., Yang, X., \& Wang, R. 2013. Current status of green curriculum in higher education of Mainland China. Journal of Cleaner Production, 61: 100-105.

Yin, R. K. 2003. Case study research: Design and methods. Thousand Oaks, CA: SAGE Publications.

Yuan, X., Zuo, J., \& Huisingh, D. 2013. Green universities in China-What matters? Journal of Cleaner Production, 61: 36-45.

Justin Edric G. Yturzaeta belongs to the first batch of graduates of the Ateneo de Manila University's Master in Sustainability Management program. He obtained an undergraduate degree in Management of Applied Chemistry with a Minor in Education also from Ateneo de Manila University and was a lecturer at the same institution before joining a corporation in the raw materials industry. 